\title{
A day out with Darwin
}

\section{John Launer}

If you want to pay homage to Britain's greatest poet and playwright, you must fight your way through the streets of Stratford-upon-Avon, alongside thousands of others who have come to visit a town that is almost entirely dedicated to Shakespeare's memory. If, by contrast, you want to pay homage to Britain's greatest scientist, you will need to take a train from London to one of its outer suburbs, wait half an hour for a bus, ask to be dropped off at a small village several miles away, and then walk for a further quarter of a mile. You will then have arrived at Down House, where Charles Darwin lived for 40 years and where he wrote On the origin of species. On a busy day, you may find a small party of visiting tourists-probably German or Scandinavian-but if you are lucky you may find yourself practically alone.

The contrast between the two sites is in many ways very puzzling. None of Shakespeare's places of residence are actually extant, whereas Down House has been restored with painstaking detail to the state it was in when Darwin lived there. His study is packed with his furniture, specimens, books, chemicals, papers and even his privy. The impression made by the whole house is so poignant, and so authentic, that one almost expects Darwin to walk in at any moment from one of his daily perambulations around his garden. Whereas one can get little or no sense of Shakespeare as an individual from a visit to Stratford, it is scarcely possible to come away from Down House without the feeling that one has, almost literally, spent the day with Darwin.

Yet in one way the contrast in popularity is not so puzzling. Britain has always had an ambivalent relationship with its scientists, and with Darwin in particular. Shakespeare's face appeared on English £20 notes from the start, but Darwin's arrived quite recently, and only on the $£ 10$ note. It is not possible to have a school education in Britain without reading some poetry and drama, whereas I doubt if any exam board would ever consider making The origin of species a set text-beautifully written though it is.

Correspondence to: Dr J Launer, London Department of Postgraduate Medical and Dental Education, Stewart House, 32 Russell Square, London WC1B 5DN, UK; jlauner@londondeanery.ac.uk
Possibly the biggest insult we offer to Darwin's memory is that everyone nowadays assumes that they know what he said, when many people have only a garbled understanding of it. Do you think that he explained how variation took place among species? Wrong. Do you imagine that he coined the phrase "survival of the fittest"? Wrong. Do you believe he argued that evolution was due solely to natural selection? Wrong. Do you know that he was a committed atheist? Wrong.

At the risk of offending readers who know their Darwin backwards, let me explain the answers to these questions. Like all his contemporaries, Darwin was totally unable to explain why variation between individuals took place, and he was frank in saying so. (We know now that it is due to chromosomal crossover and genetic mutation - both 20th century discoveries.) Darwin's genius was to work out the consequences of variation without knowing the cause; he realised how changes in the environment brought about a natural selection of any individual that happened to be in the right place at the right time.

Significantly, this was not "survival of the fittest" in the crass sense in which it is often misunderstood, and has been misapplied in the service of racism (ie, as survival of the strongest). It was survival of whichever individuals "happened to fit" the changing circumstances. A political theorist called Herbert Spencer invented the phrase that is now associated with Darwin, and although Darwin later used it on occasion, it was always a source of more misunderstanding than enlightenment.

The origin of species was all about variation and natural selection, but his second masterpiece added the next ingredient: sex. In The descent of man, Darwin demonstrated that the process of selection was not just dependent on environmental change. It also depended on sexual choice. In other words, you could be the hardiest cockroach or the most agile monkey on the planet, but if a cockroach or monkey of the opposite sex did not find you attractive, you would never conceive. So a great deal of evolution depended on males and females spotting mates who seemed the best bet in terms of both survival and adaptability.
As regards religion, Darwin's position continually shifted on this. He once confessed "my theology is a simple muddle". His wife Emma was a devoted Christian throughout her life, and their marriage was one of immense mutual love and respect. Darwin himself corresponded thoughtfully with a number of sympathetic clerics, including the delightfully quirky Rabbi Naphthali Levy of Whitechapel, who believed that there were subtle hints about natural selection in the Hebrew vowel markings in the Book of Genesis.

If we could let go of some misconceptions about what Darwin actually said, we might also be able to hold back from some of the embarrassing nonsense that sometimes passes for evolutionary thinking in medicine. The reason that people get bad backs, for example, has absolutely nothing to do with any unfitness to walk on two legs. We are perfectly adapted to walk in this way. Indeed, we could not have survived without this skill when the African rain forest retreated and our ancestors had to live in woodland and then on the savannah. If bipedalism alone was a cause of low back pain and sciatica, there would be an awful lot of kangaroos and penguins demanding MRI scans and booking appointments with osteopaths. The reason that these problems are now so common in humans is presumably because so many people adopt postures which are only very recent habits-such as sitting on chairs, or using toilets instead of squatting in the fields. Natural selection and sexual selection have not yet had time to make a difference.

A better understanding of these processes might also make us less amazed about antibiotic resistance, which is utterly inevitable over time. (If you kill off all the bacteria you can, then a few mutants you can't kill will survive, multiply and take up the same niche: a nobrainer.) It might also help us to see every other aspect of medicine, including anatomy, physiology, biochemistry and even psychology, simply as aspects of comparative zoology applied to one very recent and exceptionally self-regarding mammalian species: Homo sapiens.

Darwin suffered throughout his adult life from a variety of severe physical symptoms that may well have been psychosomatic. Some writers have suggested, quite persuasively, that these may have arisen from his sense of the enormity of what he had discovered, and of the sombre implications in terms of human selfesteem. But he was also an exceptionally 
loving man. Of all the surviving photos of him, the most moving one shows him with a look of great tenderness on his face, giving a cuddle to his son William as a toddler. His daughter Henrietta wrote about him: "he always made us feel that we were each of us creatures whose opinions and thoughts were valuable to him, so that whatever was best in us came out in the sunshine of his presence".

If you can possibly get to Down House in Kent to visit Darwin's home and gain a palpable sense of the man, you should do so. Even if you cannot, you should certainly read $O n$ the origin of species. Its stature as writing equals Shakespeare. Its vision is little short of biblical, especially in its final paragraph:

"It is interesting to contemplate an entangled bank, clothed with many plants of many kinds, with birds singing on the bushes, with various insects

flitting about, and with worms crawling through the damp earth, and reflect that these elaborately constructed forms, so different from each other, and dependent on each other in so complex a manner, have all been produced by laws acting around us... There is grandeur in this view of life, with its several powers, having been originally breathed into a few forms or into one; and that, whilst this planet has gone on cycling according to the fixed law of gravity, from so simple a beginning endless forms most beautiful and most wonderful have been, and are being, evolved."

Competing interests: None.

Postgrad Med J 2008;84:223-224.

doi:10.1136/pgmj.2008.069559

A Dees, RJ Batenburg de Jong, CA Meeuwis, et al. Carotid sinus syndrome after carotid artery surgery (Postgrad Med $J$ 1992;68:463-4). The second author's name appeared incorrectly in this article: it should be RJ Baatenburg de Jong. 